\title{
STUDIES IN ASCORBIC ACID WITH ESPECIAL REFERENCE TO THE WHITE LAYER. II. THE RELATION OF INTAKE TO BLOOD LEVELS IN NORMAL CHILDREN AND THE EFFECT OF ACUTE AND CHRONIC ILLNESS ${ }^{1}$
}

\author{
By MAY G. WILSON AND ROSE LUBSCHEZ \\ (From the New York Hospital and the Department of Pediatrics, Cornell University \\ Medical College, New York City)
}

(Received for publication January 10, 1946)

A voluminous literature has accumulated on the effect of various conditions of ascorbic acid intake on plasma levels and urinary excretion in children ( 1 to 3 ). Based on these studies, a daily allowance of 50 to $75 \mathrm{mgm}$. of ascorbic acid has been recommended for children by the National Research Council (4).

Current opinion differs as to whether or not these recommended intakes are in excess of normal requirements. This difference of opinion stems in part from the variability of plasma and urine values as related to intake and vitamin status, but in greater measure from the belief that these values are a reflection of the ascorbic acid concentration in the circulation, rather than the tissue stores $(5,6)$.

Recent studies have suggested that the level of ascorbic acid in the white cell-platelet layer probably reflects the tissue concentration of ascorbic acid. Butler and Cushman, and others consider that a low level of ascorbic acid in the white layer is a closer index of physiologically significant vitamin $\mathrm{C}$ deficiency than plasma or urinary concentration of ascorbic acid (7).

The level of ascorbic acid in the white cell-platelet layer under various conditions of ascorbic acid intake has not been studied extensively. Butler and Cushman observed white layer levels of 25 to $43 \mathrm{mgm}$. per cent in adults differing in vitamin C nutrition (5). Pijoan and Lozner found that a normal adult could maintain a level of $25 \mathrm{mgm}$. per cent for a period of months on a daily intake of $25 \mathrm{mgm}$. of ascorbic acid (6). Crandon, Lund and Dill, and Pijoan and Lozner observed that in adults who were maintained on a vitamin $C$ free diet for 4 to 6 months, the white layer level fell from a normal value of $25 \mathrm{mgm}$. per cent or more,

\footnotetext{
1 This work was aided by a special grant from the Commonwealth Fund.
}

to zero, shortly before the appearance of clinical scurvy $(8,9)$.

In a previous study of a series of ambulatory, non-febrile clinic children whose vitamin $\mathrm{C}$ intake was unknown, the range in white layer levels was found to be from 6 to $58 \mathrm{mgm}$. per cent, with the majority falling between 11 and $30 \mathrm{mgm}$. per cent (10).

The present investigation supplements the previous study. It includes observations in a series of children whose intake was known. During the course of this study, many of the children experienced intercurrent illness. These observations provided an opportunity to determine the effect of illness on blood levels at various intakes. Observations were made during the course of and convalescence from respiratory infections and childhood diseases. In addition, blood levels of ascorbic acid were determined for a series of rheumatic patients who were under concurrent observation.

\section{MATERIAL AND METHODS}

Material: There are represented in this study 76 normal children, ranging in age from 2 to 14 years, with an average age of 7 years, and 40 rheumatic subjects ranging in age from 6 to 15 years, with an average age of 10 years.

Of a total of 164 determinations in the normal group, 40 were made either during or within 2 weeks of intercurrent illnesses, such as respiratory infections, varicella, measles and scarlet fever. In the rheumatic group there were 96 determinations, of which 18 were made during intercurrent illness, and 19 were made during rheumatic activity.

All of these children have been under prolonged medical supervision at the Children's Clinic of the New York Hospital. Many have been under observation from birth. The general nutrition and development. of the normal group of children in terms of weight and height distributions at various ages compared favorably with several norms which have been established for children of a better economic status (11 to 13 ).

Complete dietary histories were obtained at clinic and 
home visits on an average of four times a year for a period of several years. In addition, the specific intake of vitamin $\mathrm{C}$ was checked each time a blood specimen was taken for analysis. From these records the average daily consumption of protein, fat, carbohydrate and total calories was estimated, using tables of food values $(14,15)$. It was found that 43 per cent of the children received 80 per cent or more of the recommended allowances of the National Research Council, and were, therefore, considered to have good general diets (4). Forty-one per cent of the children, receiving 60 to 80 per cent of the recommended allowances were considered to have fair general diets, and the remaining 16 per cent, who received less than 60 per cent of the recommended allowances, were considered to have poor general diets.

Only the consumption of citrus fruit and tomato was used for estimating the habitual intake of ascorbic acid, with the addition of $10 \mathrm{mgm}$. of ascorbic acid assumed to be contributed from all other foods, as suggested by. Bessey (2). For some subjects, the vitamin C intake included supplementary tablets of ascorbic acid.2

The data on intake were considered in terms of the total daily amount of vitamin $\mathrm{C}$ and the number of $\mathrm{mgm}$. per $\mathrm{kgm}$. body weight. A daily intake of 10 to $40 \mathrm{mgm}$. was found to be equivalent to 0.5 to $1.9 \mathrm{mgm}$. per $\mathrm{kgm}$. body weight. In this group, one-third had intakes of more than $25 \mathrm{mgm}$. For children receiving 50 to $75 \mathrm{mgm}$. a day, the intake was 1.5 to $2.9 \mathrm{mgm}$. per $\mathrm{kgm}$. body weight. For children receiving 100 to $200 \mathrm{mgm}$. a day, the intake was 3.0 to $8.9 \mathrm{mgm}$. per $\mathrm{kgm}$. body weight. On intakes of 200 to $600 \mathrm{mgm}$., the daily dosage was invariably $9 \mathrm{mgm}$. per $\mathrm{kgm}$. or more.

When changes in intake were made, it was found that the white layer levels became stabilized within one month following the change, and therefore, all intakes of one month's duration or more were considered habitual.

Methods: Serial blood specimens were collected over a. period of 3 to 10 months, 2 to 3 hours following a vitamin $\mathrm{C}$ free breakfast.s The number of specimens collected from each child ranged from 1 to 9 . In 40 per cent of the children, at least 3 specimens were collected.

The modified phenylhydrazine method of Roe and Kuether, which has been described previously, was closely followed for these analyses, (10). Four ml. of venous blood were collected in a tube containing dry mixed oxalates, care being taken to avoid hemolysis. Since it was found that both plasma and white layer specimens could be stored frozen for a period of at least two weeks without loss of ascorbic acid, the specimens were usually collected and centrifuged on one day, and analyzed several days later. The white layer specimens contained all of the platelet layer, and about 50 per cent of the leukocyte layer. No specimen weighed less than $5 \mathrm{mgm}$., and specimens in which there was possible contamination by red

\footnotetext{
$2 \mathrm{We}$ are indebted to the Mead Johnson Company for supplying the ascorbic acid tablets.

3 The cooperation and assistance of the nursing service of the Out-Patient Department in obtaining these specimens is gratefully acknowledged.
}

cells were discarded. An experimental crror of \pm 3 mgm. per cent was established for this method of white layer analysis (10). This range of error was confirmed in the present study by frequent analysis of duplicate and triplicate specimens from the same individual.

The stability of the white layer level following recent changes in intake is indicated by the following tests. Fasting determinations were made on 7 convalescent children on the pediatric pavilion of the New York Hospital prior and subsequent to an increase in intake of $500 \mathrm{mgm}$. daily for three days. Fasting specimens were then collected on the fourth, fifth and sixth days after resumption of the habitual intake. In the 21 subsequent determinations, the variation for each child was within the experimental error of the method. In only one child was there an elevation to $31 \mathrm{mgm}$. per cent in the white layer from a control level of $24 \mathrm{mgm}$. per cent. In 3 additional subjects who received $1000 \mathrm{mgm}$. in 10 divided doses for one day, the fasting white layer level, prior and subsequent to this increase in intake, differed by less than 3 mgm. per cent.

The possible diurnal fluctuations in the white layer level were also considered. In 51 determinations at 2-hour intervals during a 24-hour period on 8 volunteers from the house staff, it was found that 15 determinations varied by more than 4 , but less than $10 \mathrm{mgm}$. per cent. These variations might be attributed to the possible traumatic effect of multiple venepunctures, although hemolyzed specimens were discarded. Varying degrees of physical activity during the day might also have been a contributing factor. It is noteworthy that the fasting white layer levels on the day following the test did not differ from the initial fasting levels by more than $1 \mathrm{mgm}$. per cent.

\section{OBSERVATIONS ON NORMAL CHILDREN}

Distribution of blood levels of ascorbic acid: In Figure 1 ascorbic acid levels in the white layer at specific plasma levels are presented. It will be noted that at plasma levels of $0.4 \mathrm{mgm}$. per cent or less, there is a direct correlation. At higher plasma levels, high and low white layer levels are obtained.

At specific levels of intake of ascorbic acid, less than $9 \mathrm{mgm}$. per $\mathrm{kgm}$. body weight, there is a closer correlation between plasma and white layer levels. In Figure 2A it may be observed that on intakes of 0.5 to $1.9 \mathrm{mgm}$. per $\mathrm{kgm}$. body weight, representing for two-thirds of the subjects an intake of 15 to $25 \mathrm{mgm}$. a day, and for one-third of the subjects an intake of 25 to $40 \mathrm{mgm}$. a day, the majority of the plasma levels are $0.4 \mathrm{mgm}$. per cent or less, and two-thirds of the white layer levels are $20 \mathrm{mgm}$. per cent or less. It is noteworthy that 90 per cent of the white layer levels are less than $25 \mathrm{mgm}$. per cent. 
In Figure 2B it may be noted that on intakes of 1.5 to $2.9 \mathrm{mgm}$. per $\mathrm{kgm}$. body weight, representing the average allowance of 50 to $75 \mathrm{mgm}$. a day formulated by the National Research Council, most of the plasma levels are $0.7 \mathrm{mgm}$. per cent or more. The majority of the white layer levels are $25 \mathrm{mgm}$. per cent or more.

In Figure $2 \mathrm{C}$ it may be noted that an intake of 3.0 to $8.9 \mathrm{mgm}$. per $\mathrm{kgm}$. body weight, representing a daily dosage of at least $100 \mathrm{mgm}$. of ascorbic acid, but less than $200 \mathrm{mgm}$., the blood levels are not significantly different from the values obtained on intakes of 50 to $75 \mathrm{mgm}$. a day.

It is of particular significance that intakes of 9 mgm. per $\mathrm{kgm}$. body weight or more, representing massive dosages for at least one month of 200 to $600 \mathrm{mgm}$., the white layer level is usually less than $25 \mathrm{mgm}$. per cent (Figure 2D). It may also be noted that the plasma levels in 14 of the 33 determinations were $1.4 \mathrm{mgm}$. per cent or less, although the majority were more than $0.7 \mathrm{mgm}$. per cent. These observations were not anticipated.

To check the validity of these observations, two members of the staff, whose white layer levels had been determined at frequent intervals for one year, volunteered to take daily divided doses of 600 to $900 \mathrm{mgm}$. of ascorbic acid, in addition to their usual intake of 100 to $150 \mathrm{mgm}$. a day.

In one subject, the white layer level fell from a control level of $35 \mathrm{mgm}$. per cent to $18 \mathrm{mgm}$. per cent, with a plasma level of $1.0 \mathrm{mgm}$. per cent after a total daily intake of 700 to $750 \mathrm{mgm}$. for
3 weeks. Two weeks later the white layer level was $22 \mathrm{mgm}$. per cent on the same intake. A daily intake of 100 to $150 \mathrm{mgm}$. was then resumed, and in 3 weeks, the white layer level was $36 \mathrm{mgm}$. per cent, and the plasma level was $1.4 \mathrm{mgm}$. per cent.

In the second subject, the white layer level fell from a control level of $40 \mathrm{mgm}$. per cent to 31 mgm. per cent, with a plasma level of $1.7 \mathrm{mgm}$. per cent 2 weeks after a total daily intake of 700 to $750 \mathrm{mgm}$. had been established. The white layer level fluctuated between 30 and $34 \mathrm{mgm}$. per cent in the next 5 weeks, during the last 3 of which the intake was increased to 1000 to $1050 \mathrm{mgm}$. a day. After 4 weeks on the increased dosage, the white layer level was $16 \mathrm{mgm}$. per cent, with a plasma level of $0.7 \mathrm{mgm}$. per cent. The 24-hour urinary excretion was then determined, and it was found that $600 \mathrm{mgm}$. were excreted on one day, and $941 \mathrm{mgm}$. were excreted 3 days later. Two weeks after the resumption of a daily intake of 100 to $150 \mathrm{mgm}$. the white layer level was $32 \mathrm{mgm}$. per cent, the plasma level $1.1 \mathrm{mgm}$. per cent, and the urinary excretion was $38 \mathrm{mgm}$.

It is of interest that in both subjects, the total and differential white counts remained within normal limits.

\section{COMMENT}

It is apparent that intakes of approximately 25 mgm. a day will not consistently maintain a level of $25 \mathrm{mgm}$. per cent in the white layer of well child-

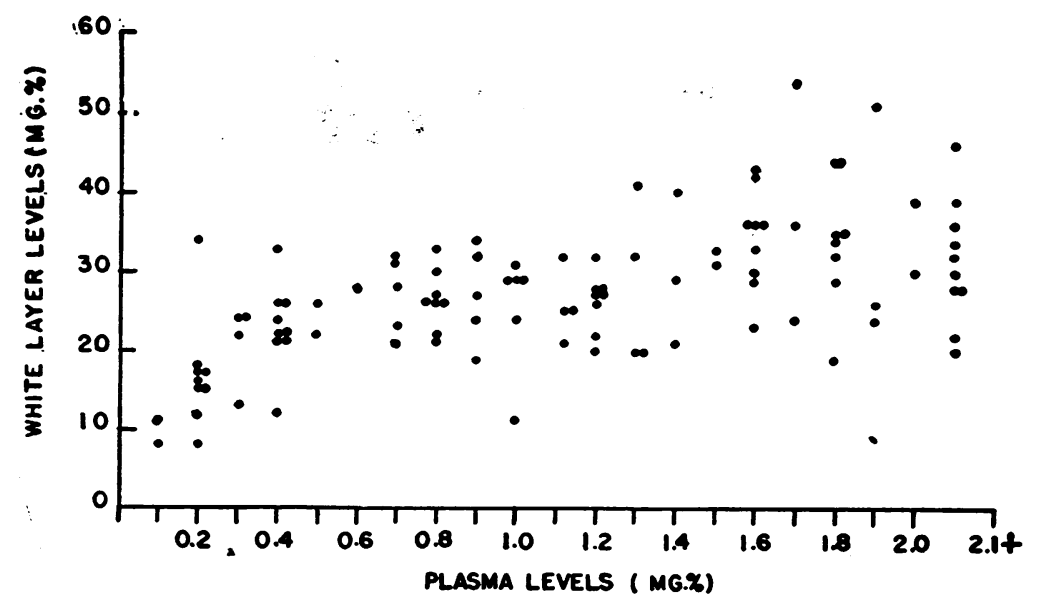

Fig. 1. Ascorbic Acid Levels in Plasma and White Layer in Normal Children on Intakes of 0.5 to 8.9 mgM. Per kgM. Body Weight (15 to 200 MgM. of AsCorbic ACId A DAY) 
A.
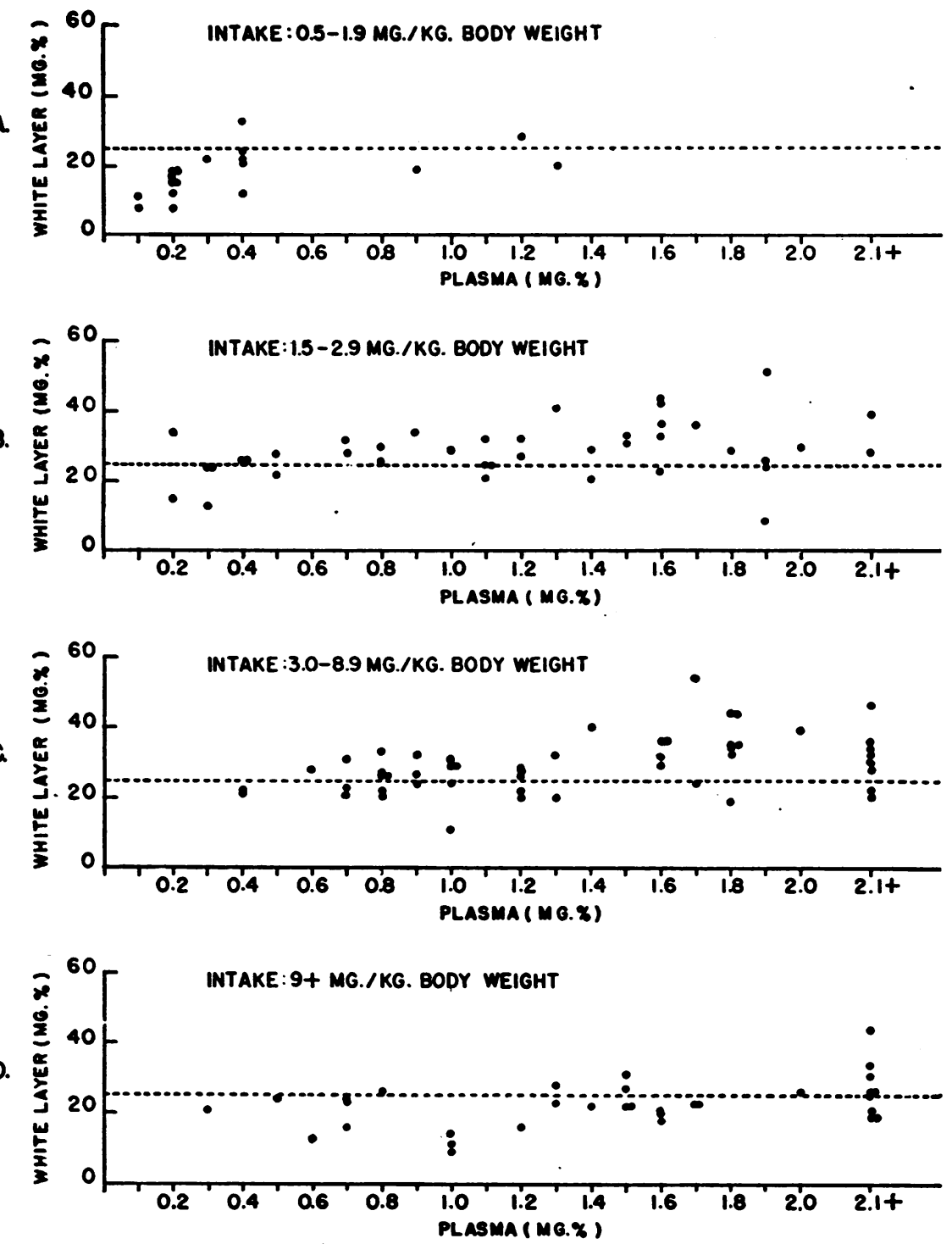

Fig. 2. Plasma and White Layer Levels at Various Intakes of Ascorbic Acid

A. Intakes of 15 to $40 \mathrm{mgm}$. a day.

B. Intakes of 50 to $75 \mathrm{mgm}$. a day.

C. Intakes of 100 to $200 \mathrm{mgm}$. a day.

D. Intakes of 200 to $600 \mathrm{mgm}$. a day (including 16 normal subjects and 17 well rheumatic subjects).

ren. This is contrary to the observations by Pijoan and Lozner in an adult (8).

Of particular interest is the observation that the majority of children receiving the recommended allowance of 50 to $75 \mathrm{mgm}$. a day, formulated by the National Research Council, maintained levels of $25 \mathrm{mgm}$. per cent or more during apparent health.
It might be questioned whether intakes sufficient to maintain a level of $25 \mathrm{mgm}$. per cent are necessary. We have obtained no evidence to indicate that children with such levels had any advantage over others with lower levels. The small number of children on low intakes of vitamin $C$ were also those who had inadequate diets. Among these children, poor nutrition and frequent illness could 
not be attributed to a specific inadequacy of vitamin $\mathrm{C}$ intake. However, it is reasonable to assume that concomitant with the gradually lowering level of ascorbic acid in the white layer in the weeks preceding manifest scurvy, there are early tissue changes. It would therefore, seem desirable to provide an intake of ascorbic acid sufficient to maintain the white layer level at $25 \mathrm{mgm}$. per cent or more. It should be borne in mind that dietary surveys of school children have reported that the majority of children do not receive an orange or its equivalent every day.

It is apparent that massive dosage of ascorbic acid, given over a period of one month or more to children whose previous intake was adequate, is not advisable. Unless the previous level is low, intakes of $9 \mathrm{mgm}$. per $\mathrm{kgm}$. body weight or more often depress the white layer level below $25 \mathrm{mgm}$. per cent. In addition, several children did not appear to tolerate massive dosage over a prolonged period. Anorexia, abdominal pain and erythematous eruptions were noted, which could not be attributed to other factors (Table I).

\section{OBSERVATIONS ON CHILDREN WITH INTERCURRENT ILLNESS}

Distribution of blood levels of ascorbic acid: The previous observations represent blood levels of ascorbic acid in children who were in apparent good health for the preceding two weeks or more. In Table IIB are summarized the white layer levels for children on various intakes, who experienced respiratory infections or childhood diseases within two weeks of the time of analysis. Of particular importance is the fact that lower levels are observed on intakes of 1.5 to $2.9 \mathrm{mgm}$. per $\mathrm{kgm}$. body weight than for well children on the same intakes (Table IIA). On intakes of 3.0 to $8.9 \mathrm{mgm}$. per $\mathrm{kgm}$. body weight, the majority of the levels are above $25 \mathrm{mgm}$. per cent. It is also of interest that

TABLE I

The response of plasma and white layer levels of ascorbic acid to various intakes in a representative group of cases

\begin{tabular}{|c|c|c|c|c|c|c|c|c|c|c|c|}
\hline \multirow{2}{*}{$\underset{\text { ject }}{\text { Sub- }}$} & \multirow{2}{*}{$\begin{array}{c}\text { Age } \\
\text { (years) }\end{array}$} & \multirow{2}{*}{$\begin{array}{c}\text { Average } \\
\text { Weight (kgm.) }\end{array}$} & \multicolumn{9}{|c|}{ Serial determinations } \\
\hline & & & 1 & 2 & 3 & 4 & 5 & 6 & 7 & 8 & 9 \\
\hline \multicolumn{3}{|c|}{$\begin{array}{l}\text { A. Non-Rheumatic Subjects: } \\
\text { P.S. 8 } 89 \\
\text { Plasma (mgm. per cent) } \\
\text { White Layer (mgm. per cent) } \\
\text { Intake (mgm. per kgm. body wt.) } \\
\text { Duration of Intake } \\
\text { Remarks }\end{array}$} & $\begin{array}{c}11 / 4 / 44 \\
1.7 \\
54 \\
3.7 \\
\text { Habitual } \\
\text { Well }\end{array}$ & $\begin{array}{c}12 / 9 / 44 \\
2.1 \\
31 \\
5.4 \\
1 \text { month } \\
\text { Febrile }\end{array}$ & $\begin{array}{c}1 / 6 / 45 \\
1.8 \\
44 \\
7.0 \\
1 \text { month } \\
\text { Well }\end{array}$ & $\begin{array}{c}3 / 31 / 45 \\
1.4 \\
40 \\
7.0 \\
3 \text { months } \\
\text { Well }\end{array}$ & $\begin{array}{l}6 / 16 / 45 \\
2.2 \\
26 \\
21.6 \\
1 \text { month } \\
\text { Well }\end{array}$ & & & & \\
\hline \multicolumn{3}{|c|}{$\begin{array}{l}\text { E.L. } 2 \text { Plasma (mgm. per cent) } \\
\text { White Layer (mgm. per cent) } \\
\text { Intake (mgm. per kgm. body wt.) } \\
\text { Duration of Intake } \\
\text { Remarks }\end{array}$} & $\begin{array}{c}11 / 25 / 44 \\
0.1 \\
8 \\
0.9 \\
\text { Habitual } \\
\text { Well }\end{array}$ & $\begin{array}{c}2 / 24 / 45 \\
1.8 \\
34 \\
8.0 \\
3 \text { months } \\
\text { Well }\end{array}$ & $\begin{array}{c}5 / 26 / 45 \\
1.0 \\
31 \\
7.2 \\
3 \text { months } \\
\text { Well }\end{array}$ & $\begin{array}{l}\text { 6/23/45 } \\
1.0 \\
25 \\
35.0 \\
1 \text { month } \\
\text { Febrile } \\
\text { (U.R.I.) } \\
\text { Erythema }\end{array}$ & & & & & \\
\hline \multicolumn{3}{|c|}{$\begin{array}{l}\text { P.B. } 8 \\
\text { Plasma (mgm. per cent) } \\
\text { White Layer (mgm. per cent) } \\
\text { Intake (mgm. per kgm. body wt.) } \\
\text { Duration of Intake } \\
\text { Remarks }\end{array}$} & $\begin{array}{c}11 / 18 / 44 \\
0.7 \\
32 \\
1.9 \\
2 \text { weeks } \\
\text { Well }\end{array}$ & $\begin{array}{c}12 / 28 / 44 \\
2.4 \\
34 \\
3.7 \\
1 \text { month } \\
\text { Well }\end{array}$ & $\begin{array}{c}2 / 17 / 45 \\
1.6 \\
30 \\
3.5 \\
2 \text { months } \\
\text { Febrile } \\
\text { (U.R.I.) }\end{array}$ & $\begin{array}{c}5 / 19 / 45 \\
1.7 \\
24 \\
4.5 \\
3 \text { months } \\
\text { Well }\end{array}$ & $\begin{array}{c}6 / 29 / 45 \\
2.1 \\
19 \\
18.0 \\
1 \text { month } \\
\text { Well }\end{array}$ & & & & \\
\hline \multicolumn{3}{|c|}{$\begin{array}{l}\text { E.Q. } 60 \\
\text { Plasma (mgm. per cent) } \\
\text { White Layer (mgm. per cent) } \\
\text { Intake (mgm. per kgm. body wt.) } \\
\text { Duration of Intake } \\
\text { Remarks }\end{array}$} & $\begin{array}{c}1 / 6 / 45 \\
1.2 \\
27 \\
3.8 \\
\text { Habitual } \\
\text { Well }\end{array}$ & $\begin{array}{c}2 / 24 / 45 \\
0.7 \\
24 \\
10.0 \\
2 \text { months } \\
\text { Well }\end{array}$ & $\begin{array}{l}3 / 24 / 45 \\
0.5 \\
20 \\
7.6 \\
1 \text { month } \\
\text { Febrile } \\
\text { (U.R.I.) }\end{array}$ & $\begin{array}{l}5 / 26 / 45 \\
0.7 \\
23 \\
15.0 \\
2 \text { months } \\
\text { Well }\end{array}$ & $\begin{array}{l}6 / 27 / 45 \\
1.3 \\
23 \\
24.6 \\
1 \text { month } \\
\text { Well }\end{array}$ & & & & \\
\hline \multicolumn{3}{|c|}{$\begin{array}{l}\text { T.S. } 60 \\
\text { Plasma (mgm. per cent) } \\
\text { White Layer (mgm. per cent) } \\
\text { Intake (mgm. per kgm. body wt.) } \\
\text { Duration of Intake } \\
\text { Remarks }\end{array}$} & $\begin{array}{c}11 / 25 / 44 \\
1.9 \\
26 \\
2.7 \\
\text { Habbitual } \\
\text { Well }\end{array}$ & $\begin{array}{l}1 / 29 / 45 \\
1.6 \\
36 \\
5.2 \\
2 \text { months } \\
\text { Well }\end{array}$ & $\begin{array}{c}4 / 14 / 45 \\
1.7 \\
33 \\
5.0 \\
2 \text { months } \\
\text { Well }\end{array}$ & $\begin{array}{l}6 / 27 / 45 \\
1.6 \\
20 \\
26.0 \\
1 \text { month } \\
\text { Well }\end{array}$ & & & & & \\
\hline \multicolumn{3}{|c|}{$\begin{array}{l}\text { D.S. } 4 \\
\text { Plasma (mgm. per cent) } \\
\text { White Layer (mgm. per cent). } \\
\text { Intake (mgm. per kgm. body wt.) } \\
\text { Duration of Intake } \\
\text { Remarks }\end{array}$} & $\begin{array}{c}11 / 25 / 44 \\
1.8 \\
29 \\
3.5 \\
\text { Habitual } \\
\text { Well }\end{array}$ & $\begin{array}{c}1 / 29 / 45 \\
1.2 \\
26 \\
6.9 \\
2 \text { months } \\
\text { Well }\end{array}$ & $\begin{array}{c}4 / 14 / 45 \\
2.0 \\
34 \\
6.8 \\
2 \text { months } \\
\text { Well }\end{array}$ & $\begin{array}{c}6 / 27 / 45 \\
2.1 \\
19 \\
33.5 \\
1 \text { month } \\
\text { Well }\end{array}$ & & & & & \\
\hline
\end{tabular}


TABLE I-Continued

\begin{tabular}{|c|c|c|c|c|c|c|c|c|c|c|c|}
\hline \multirow{2}{*}{$\begin{array}{l}\text { Sub- } \\
\text { ject }\end{array}$} & \multirow{2}{*}{$\begin{array}{c}\text { Age } \\
\text { (years) }\end{array}$} & \multirow{2}{*}{$\begin{array}{c}\text { Average } \\
\text { Weight (kgm.) }\end{array}$} & \multicolumn{9}{|c|}{ Serial determinations } \\
\hline & & & 1 & 2 & 3 & 4 & 5 & 6 & 7 & 8 & 9 \\
\hline \multicolumn{3}{|c|}{$\begin{array}{l}\text { B. Rheumatic Subjects: } \\
\text { E.Q. } 8 \\
\text { Plasma (mgm. per cent) } \\
\text { White Layer (mgm. per cent) } \\
\text { Intake (mgm. per kgm. body wt.) } \\
\text { Duration of Intake } \\
\text { Remarks }\end{array}$} & $\begin{array}{l}1 / 6 / 45 \\
1.2 \\
27 \\
11.6 \\
2 \text { months } \\
\text { Febrile } \\
\text { Chorea }\end{array}$ & $\begin{array}{c}2 / 24 / 45 \\
0.8 \\
31 \\
13.5 \\
2 \text { months } \\
\text { Chorea }\end{array}$ & $\begin{array}{c}3 / 24 / 45 \\
1.1 \\
27 \\
15.8 \\
1 \text { month } \\
\text { Febrile } \\
\text { Chorea }\end{array}$ & $\begin{array}{l}5 / 26 / 45 \\
0.6 \\
13 \\
10.5 \\
2 \text { months } \\
\text { Well }\end{array}$ & $\begin{array}{l}6 / 27 / 45 \\
1.2 \\
16 \\
17.3 \\
1 \text { month } \\
\text { Well }\end{array}$ & & & & \\
\hline \multicolumn{3}{|c|}{$\begin{array}{l}\text { G.E. } 15 \\
\text { Plasma (mgm. per cent) } \\
\text { White Layer (mgm. per cent) } \\
\text { Intake (mgm. per kgm. body wt.) } \\
\text { Duration of Intake } \\
\text { Remarks }\end{array}$} & $\begin{array}{c}2 / 28 / 45 \\
0.8 \\
32 \\
1.2 \\
1 \text { month } \\
\text { Active Rh. }\end{array}$ & $\begin{array}{c}3 / 3 / 45 \\
1.6 \\
31 \\
17.1 \\
1 \text { day } \\
\text { Active Rh. }\end{array}$ & $\begin{array}{c}3 / 17 / 45 \\
1.6 \\
35 \\
10.0 \\
1 \text { month } \\
\text { Active Rh. }\end{array}$ & $\begin{array}{c}4 / 14 / 45 \\
1.3 \\
26 \\
4.8 \\
1 \text { month } \\
\text { Active Rh. }\end{array}$ & $\begin{array}{c}5 / 19 / 45 \\
1.3 \\
21 \\
4.5 \\
1 \text { month } \\
\text { Well }\end{array}$ & $\begin{array}{c}6 / 9 / 45 \\
1.3 \\
28 \\
8.7 \\
3 \text { weeks } \\
\text { Well }\end{array}$ & & & \\
\hline \multicolumn{3}{|c|}{$\begin{array}{l}\text { H.A. } 10 \\
\text { Plasma (mgm. per cent) } \\
\text { White Layer (mgm. per cent) } \\
\text { Intake (mgm. per kgm. body wt.) } \\
\text { Duration of Intake } \\
\text { Remarks }\end{array}$} & $\begin{array}{c}11 / 11 / 44 \\
2.4 \\
44.9 \\
12.9 \\
\text { Habitual } \\
\text { Well }\end{array}$ & $\begin{array}{l}12 / 16 / 45 \\
1.8 \\
41 \\
10.9 \\
1 \text { month } \\
\text { Recent } \\
\text { U.R.I. }\end{array}$ & $\begin{array}{c}2 / 17 / 45 \\
2.1 \\
39 \\
8.5 \\
2 \text { months } \\
\text { Well }\end{array}$ & $\begin{array}{l}5 / 19 / 45 \\
1.1 \\
22 \\
11.7 \\
3 \text { months } \\
\text { Erythema }\end{array}$ & $\begin{array}{c}5 / 29 / 45 \\
1.4 \\
23 \\
11.7 \\
2 \text { weeks } \\
\text { Erythema } \\
\text { Abdominal } \\
\text { Pain }\end{array}$ & $\begin{array}{c}6 / 9 / 45 \\
1.5 \\
27 \\
9.3 \\
2 \text { weeks } \\
\text { Well } \\
\text { Abdominal } \\
\text { Pain }\end{array}$ & & & \\
\hline \multicolumn{3}{|c|}{$\begin{array}{l}\text { M.H. } 13 \\
\text { Plasma (mgm. per cent) } \\
\text { White Layer (mgm. per cent) } \\
\text { Intake (mgm. per kgm. body wt.) } \\
\text { Duration of Intake } \\
\text { Remarks }\end{array}$} & $\begin{array}{c}11 / 11 / 44 \\
0.2 \\
12 \\
0.4 \\
\text { Habitual } \\
\text { Febrile } \\
\text { (U.R.I.) }\end{array}$ & $\begin{array}{l}12 / 28 / 44 \\
0.9 \\
42 \\
12.8 \\
1 \text { month } \\
\text { Febrile } \\
\text { (U.R.I.) }\end{array}$ & $\begin{array}{c}2 / 10 / 45 \\
0.9 \\
29 \\
3.5 \\
2 \text { months } \\
\text { Active Rh. }\end{array}$ & $\begin{array}{c}2 / 17 / 45 \\
0.6 \\
17 \\
3.5 \\
\text { 1 week } \\
\text { Active Rh. }\end{array}$ & $\begin{array}{c}3 / 24 / 45 \\
1.7 \\
26 \\
13.0 \\
1 \text { month } \\
\text { Active Rh. }\end{array}$ & $\begin{array}{l}4 / 21 / 45 \\
1.2 \\
26 \\
13.5 \\
1 \text { month } \\
\text { Febrile } \\
\text { (U.R.I.) }\end{array}$ & $\begin{array}{l}5 / 8 / 45 \\
0.6 \\
15 \\
14.2 \\
2 \text { weeks } \\
\text { Recent } \\
\text { U.R.I. }\end{array}$ & $\begin{array}{c}5 / 26 / 45 \\
0.5 \\
24 \\
14.2 \\
2 \text { weeks } \\
\text { Well (Pete } \\
\text { months }\end{array}$ & $\begin{array}{l}\text { hiae } 2 \\
\text { ater) }\end{array}$ \\
\hline \multicolumn{3}{|c|}{$\begin{array}{l}\text { J.S. } 11 \\
\text { Plasma (mgm. per cent) } \\
\text { White Layer (mgm. per cent) } \\
\text { Intake (mgm. per kgm. body wt.) } \\
\text { Duration of Intake } \\
\text { Remarks }\end{array}$} & $\begin{array}{c}4 / 14 / 45 \\
1.0 \\
29 \\
2.9 \\
2 \text { weeks } \\
\text { Well }\end{array}$ & $\begin{array}{l}4 / 28 / 45 \\
1.2 \\
26 \\
11.5 \\
2 \text { weeks } \\
\text { Well }\end{array}$ & $\begin{array}{c}6 / 27 / 45 \\
1.0 \\
11 \\
8.2 \\
2 \text { months } \\
\text { Well }\end{array}$ & & & & & & \\
\hline \multicolumn{3}{|c|}{$\begin{array}{l}\text { W.K. } 8 \\
\text { Plasma (mgm. per cent) } \\
\text { White Layer (mgm. per cent) } \\
\text { Intake (mgm. per kgm. body wt.) } \\
\text { Duration of Intake } \\
\text { Remarks }\end{array}$} & $\begin{array}{c}12 / 16 / 44 \\
1.9 \\
40 \\
6.3 \\
1 \text { month } \\
\text { Well }\end{array}$ & $\begin{array}{c}2 / 24 / 45 \\
1.7 \\
32 \\
6.3 \\
2 \text { months } \\
\text { Well }\end{array}$ & $\begin{array}{c}3 / 24 / 45 \\
1.3 \\
34 \\
6.4 \\
1 \text { month } \\
\text { Well }\end{array}$ & $\begin{array}{l}6 / 2 / 45 \\
2.1 \\
26 \\
13.0 \\
2 \text { months } \\
\text { Well }\end{array}$ & & & & & \\
\hline
\end{tabular}

on massive dosage a greater number of white layer levels are above $25 \mathrm{mgm}$. per cent than in the group in apparent good health.

Blood levels in rheumatic patients: In Table IIIA, it may be noted that there is no significant difference in the blood levels on various intakes for rheumatic subjects in apparent good health, in comparison to well, non-rheumatic subjects (Table IIA). There were, however, more white layer levels above $25 \mathrm{mgm}$. per cent in the group receiving massive dosage than in the comparable non-rheumatic group.

Although the number of observations of rheumatic subjects during intercurrent illness is limited, it may be observed in Table IIIB that the distribution of blood levels is similar to that observed for the comparable non-rheumatic group. In several children on low intakes the white layer levels were 10 to $15 \mathrm{mgm}$. per cent.

For the few subjects who experienced an acute rheumatic episode, it may be noted in Table IIIC that the majority of the white layer levels are lower at all levels of intake. In several rheumatic patients who had received massive dosage of ascorbic acid over a period of months, anorexia, abdominal pain and petechiae were noted (Table I).

\section{DISCUSSION}

The difficulties inherent in the assessment of dietary histories were minimized in this study. The families were under close medical supervision over a prolonged period of observation, during which time there was ample opportunity to estimate the accuracy and reliability of the dietary records. Corroborative evidence is given by the consistency of the blood levels of ascorbic acid at any specific intake. It was observed that within a family, recorded differences in ascorbic acid intake for each child were consistent with the levels of ascorbic acid in the white layer. The majority 
TABLE II

White layer levels at various intakes in normal children during health and intercurrent illness

\begin{tabular}{c|c|c|c}
\hline \hline Intake & \multicolumn{2}{|c|}{$\begin{array}{c}\text { Distribution of white layer levels } \\
\text { (mgm. per cent) }\end{array}$} & $\begin{array}{c}\text { Total } \\
\text { obser- } \\
\text { vations }\end{array}$ \\
\cline { 1 - 3 } $\begin{array}{c}\text { (mgm. per kgm. } \\
\text { body wt.) }\end{array}$ & $<15 \mid 16$ to 20|21 to 24|25 to 35 & $36+$ & \\
\hline
\end{tabular}

A. Normal subjects

\begin{tabular}{l|l|l|r|r|l|l}
\hline 0.5 to 1.9 & 7 & 5 & 4 & 2 & & 18 \\
1.5 to 2.9 & 2 & 1 & 7 & 23 & 7 & 40 \\
3.0 to 8.9 & 1 & 4 & 11 & 25 & 9 & 50 \\
$\cdots \cdots 9.0+$ & 1 & 5 & 6 & 4 & & 16 \\
\hline
\end{tabular}

B. Normal subjects with intercurrent illness

\begin{tabular}{l|l|l|l|r|r|r}
\hline 0.5 to 1.9 & 3 & 1 & & & & 4 \\
1.5 to 2.9 & 1 & 1 & 3 & 5 & & 10 \\
3.0 to 8.9 & & 1 & 6 & 12 & & 19 \\
$\cdots . .99 .0+$ & & 1 & 1 & 5 & & 7 \\
\hline
\end{tabular}

of the children whose general diet was estimated as adequate were of good nutrition and compared favorably with a series of observations on normal children of a higher economic status.

It has been shown that a single white layer specimen is reliable from the standpoint of chemical analysis. It is evident that a fasting specimen is preferable, since some diurnal fluctuation was observed in serial specimens. Since the majority of the serial determinations did not differ by more than $4 \mathrm{mgm}$. per cent, the fluctuations observed were interpreted to be of no clinical significance.

The observations on the relation of intake of ascorbic acid to the level in the white layer are interpreted to indicate that the recommended allowance of 50 to $75 \mathrm{mgm}$. a day formulated by the National Research Council is not excesive. When this intake represents a dosage of 1.5 to $2.9 \mathrm{mgm}$. per $\mathrm{kgm}$. body weight, levels of $25 \mathrm{mgm}$. per cent were maintained by children who were in apparent good health.

It is of interest that Roberts and Roberts (16), in an intensive study of 5 children, observed that on a range in intake of 1.7 to $2.4 \mathrm{mgm}$. per kgm. body weight, representing 65 to $75 \mathrm{mgm}$. a day of pure ascorbic acid, a plasma level of $0.7 \mathrm{mgm}$. per cent was maintained. This intake was sufficient to provide for an average retention value and to produce a 50 per cent excretion of a test dose. The findings of Bessey and White (2) in a series of ambulatory children on an estimated intake of about $50 \mathrm{mgm}$. a day, are in essential agreement. The majority of the well children in this study on intakes of $50 \mathrm{mgm}$. a day or more maintained plasma levels of $0.7 \mathrm{mgm}$. per cent or more. It is probable that when there is no recent change in vitamin $\mathrm{C}$ intake, both plasma levels and urinary excretion reflect the intake of ascorbic acid. However, it was observed that following recent changes in intake, plasma and urine values varied significantly, while the white layer level remained constant. Since white layer levels do not vary following recent changes in intake, it would appear that the white layer level is a more reliable criterion of habitual intake of ascorbic acid than plasma or urine values.

The tendency to consider vitamin $\mathrm{C}$ requirements only from the standpoint of the prevention of scurvy would not appear advisable for children. If the level in the white layer reflects in any measure the tissue concentration of ascorbic acid, an intake sufficient to insure the maintenance of normal levels should be given. On intakes of less than $40 \mathrm{mgm}$. a day, the white layer levels approached the prescorbutic values observed in experimentally induced scurvy.

It has been shown that during the course of acute or chronic illness, or during convalescence,

TABLE III

White layer levels at various intakes in rheumatic subjects

\begin{tabular}{|c|c|c|c|c|c|}
\hline \multirow{2}{*}{$\frac{\text { Intake }}{\left(\begin{array}{c}\text { (mgm. per kgm. } \\
\text { body wt.) }\end{array}\right.}$} & \multicolumn{4}{|c|}{$\begin{array}{l}\text { Distribution of white layer levels } \\
\text { (mgm. per cent) }\end{array}$} & \multirow{2}{*}{$\begin{array}{l}\text { Total } \\
\text { obser- } \\
\text { vations }\end{array}$} \\
\hline & $<15$ & 16 to 2021 to 24 & 25 to 35 & $36+$ & \\
\hline
\end{tabular}

A. Well rheumatic subjects

\begin{tabular}{l|l|l|l|r|r|r}
0.5 to 1.9 & 3 & 3 & 1 & 1 & & 8 \\
1.5 to 2.9 & & 1 & 3 & 3 & & 7 \\
3.0 to 8.9 & 1 & 2 & 4 & 13 & 7 & 27 \\
$\cdots . .99 .0+$ & 3 & 1 & 6 & 6 & 1 & 17 \\
\hline
\end{tabular}

B. Rheumatic subjects with intercurrent illness

\begin{tabular}{l|l|l|l|l|l|l}
0.5 to 1.9 & 2 & 2 & & & & 4 \\
1.5 to 2.9 & 1 & 2 & & 2 & & 3 \\
3.0 to 8.9 & 2 & 2 & & 2 & 2 & 6 \\
$\cdots . .99 .0+$ & 2 & & & 6 \\
\hline
\end{tabular}

C. Rheumatic subjects with acute rheumatic fever

\begin{tabular}{l|l|l|l|l|l|l}
0.5 to 1.9 & & & & & & \\
1.5 to 2.9 & 1 & & 1 & 2 & & 4 \\
3.0 to 8.9 & 1 & 1 & 1 & 3 & 1 & 7 \\
$\cdots . .99 .0+$ & 1 & & 2 & 5 & & 8 \\
\hline
\end{tabular}


blood levels were lowered. The mean white layer level on daily intakes of 1.5 to $2.9 \mathrm{mgm}$. per $\mathrm{kgm}$. body weight ( 50 to $75 \mathrm{mgm}$.) was 24.2 compared to 28.9 for well children. While intakes of 1.5 to 2.9 mgm. per kgm. body weight will maintain normal levels during health, it would seem desirable to insure an adequate margin of reserve by providing larger intakes, since most children have repeated illnesses. It has been observed that during acute and chronic illness, an intake of at least $100 \mathrm{mgm}$. a day will maintain white layer levels above 25 mgm. per cent. Such an intake would seem to be particularly indicated for growing children, experiencing frequent febrile illnesses, and for those suffering from chronic diseases, such as rheumatic fever. No evidence was obtained to indicate that the requirements for rheumatic fever differ from those in other acute febrile illnesses.

The observed depression of the level of ascorbic acid in the white layer on intakes of $9 \mathrm{mgm}$. per $\mathrm{kgm}$. or more, is of considerable interest, but difficult or impossible to interpret at the present time. The excess of ascorbic acid over body requirements may be stored, destroyed, or excreted unchanged. The variability of the urinary output makes it difficult to account for the total amount ingested on the basis of the plasma, white cell and urinary content of ascorbic acid. It is probable that varying amounts of ascorbic acid are destroyed, and the depression of the white layer level after prolonged massive dosage suggests that such destruction may be carried beyond normal limits. In this connection, it is of interest to note that the fasting plasma level rises as high as $2.3 \mathrm{mgm}$. per cent early in the course of massive dosage, but by the time the white layer level is lowered, the fasting plasma level is usually between 0.7 and $1.0 \mathrm{mgm}$. per cent. It is possible that the normal renal threshold may be lowered after prolonged therapy.

Although it has generally been observed that crystalline ascorbic acid is non-toxic in moderate doses, there have been reports of vagotonic symptoms in growing children at the height of vitamin $C$ action (17). Fatigue, anorexia, increased peristalsis, dermography and erythema have been attributed to sensitivity or idiosyncrasy to ascorbic acid. Comparable symptoms were noted in several children in our series who were on massive dosage. Randoin has noted that if a scorbutic animal is given relatively larger quantities of vitamin $C$ the animal may lose weight, and the symptoms of scurvy reappear (17).

It has generally been assumed that the amount of ascorbic acid ingested in excess of body requirements is excreted, and is therefore wasteful. Some evidence has been presented that massive dosage of ascorbic acid may be detrimental. It would, therefore, seem inadvisable to administer massive doses of ascorbic acid over a prolonged period of time in children whose previous intake has been adequate.

\section{SUM MARY}

1. In normal children, the range in plasma levels of ascorbic acid varied between 0.1 and 2.1 mgm. per cent, and the white layer levels ranged between 8 and $54 \mathrm{mgm}$. per cent on intakes of ascorbic acid of 0.5 to $8.9 \mathrm{mgm}$. per $\mathrm{kgm}$. body weight, (15 to $200 \mathrm{mgm}$. a day).

2. On habitual daily intakes of 0.5 to $1.9 \mathrm{mgm}$. per $\mathrm{kgm}$. body weight (average intake of about $25 \mathrm{mgm}$.), the plasma levels were consistently 0.4 mgm. per cent or less, and the white layer levels were $20 \mathrm{mgm}$. per cent or less.

3. On habitual daily intakes of 1.5 to $2.9 \mathrm{mgm}$. per $\mathrm{kgm}$. body weight (average intake 50 to 75 mgm.), the majority of the plasma levels were 0.7 mgm. per cent or more, and the white layer levels were $25 \mathrm{mgm}$. per cent or more in well children.

4. On daily intakes of $9 \mathrm{mgm}$. per $\mathrm{kgm}$. body weight or more (200 to $600 \mathrm{mgm}$. a day) for a period of at least one month, the majority of the white layer levels were less than $25 \mathrm{mgm}$. per cent, and one-third of the plasma levels was less than 1.4 mgm. per cent.

5. During the course or convalescence from intercurrent febrile illness, intakes of 3.0 to $8.9 \mathrm{mgm}$. per $\mathrm{kgm}$. body weight (100 to $200 \mathrm{mgm}$. a day) were necessary to maintain white layer levels of $25 \mathrm{mgm}$. per cent or more.

6. Blood levels in rheumatic subjects did not differ from those found in comparable non-rheumatic subjects on the same intakes.

\section{CONCLUSIONS}

1. The recommended daily allowance of 50 to $75 \mathrm{mgm}$. of ascorbic acid for children formulated by the National Research Council is not excessive. 
2. To insure the maintenance of levels of 25 mgm. per cent or more in the white layer during childhood, habitual intakes of 3.0 to $8.9 \mathrm{mgm}$. per $\mathrm{kgm}$. body weight (at least $100 \mathrm{mgm}$. a day) are necessary.

3. Habitual intakes of $9 \mathrm{mgm}$. per $\mathrm{kgm}$. body weight (200 to $600 \mathrm{mgm}$. a day) or more are unnecessary and inadvisable.

We gratefully acknowledge the constructive criticism and suggestions of Dr. Otto A. Bessey and Dr. Oliver H. Lowry during the progress of this study.

\section{BIBLIOGRAPHY}

1. Smith, S. L., Human requirements of vitamin C. J. A. M. A., 1938, 111, 1753.

2. Bessey, O. A., and White, R. L., The ascorbic acid requirements of children. J. Nutrition, 1942, 23, 195.

3. Minot, A: S., Dodd, K., Keller, M., and Frank, H., A survey of the state of nutrition with respect to vitamin C in a southern pediatric clinic. J. Pediat., 1940, 16, 717.

4. Food and Nutrition Board, National Research Council, Recommended Dietary Allowances. Revised 1945, Nutrition Rev., 1945, 3, 287.

5. Butler, A. M., and Cushman, M., Distribution of ascorbic acid in the blood and its nutritional significance. .J. Clin. Invest., 1940, 19, 459.
6. Pijoan, M., and Lozner, E. L., The physiologic significance of vitamin $C$ in man. New England J. Med., 1944, 231, 14.

7. Butler, A. M., Vitamin C deficiency. M. Clin. North America, 1943, 27, 441.

8. Pijoan, M., and Lozner, E. L., Vitamin C economy in the human subject. Bull. Johns Hopkins Hosp., 1944, 75, 303.

9. Crandon, J. H., Lund, C. C., and Dill, D. B., Experimental human scurvy. New England J. Med., 1940, 223, 353.

10. Lubschez, R., Studies in ascorbic acid with especial reference to the white layer. I. Description of method. J. Clin. Invest., 1945, 24, 573.

11. Sontag, L. W., and Reynolds, E. L., Fels composite sheet. J. Pediat., 1945, 26, 327.

12. Wetzel, N. C., Physical fitness in terms of physique, development and basal metabolism. J. A. M. A., 1941, 116, 1187.

13. Jackson, R. L., and Kelly, H. G., Growth charts for use in pediatric practice. J. Pediat., 1945, 27, 215.

14. Bowes, A., and Church, C. F., Food values of portions commonly used. Philadelphia Child Health Society, Philadelphia, 1942.

15. Bradley, A. V., Tables of Food Values. The Manual Arts Press, Peoria, Ill., 1942.

16. Roberts, V. M., and Roberts, L. J., A study of ascorbic acid requirements of children of early school age. J. Nutrition, 1942, 24, 25.

17. Abt, A. F., and Farmer, C. J., Vitamin C, pharmacology and therapeutics. J. A. M. A., 1938, 111, 1555. 